hydrophila, Aeromonas salmonicida subsp. salmonicida). Зразки листків було зібрано в Національному ботанічному саду імені М. М. Гришка (НБС, Київ, Украӥна) та Ботанічному саду Львівського національного університету імені Івана Франка (Львів, Україна). Свіжсозібрані листки зважували та гомогенізували в 96\%-ному етанолі (у співвідношенні 1:10) при кімнатній температурі. Три штами Аeromonas: Aeromonas sobria (K825), Aeromonas hydrophila (K886), a також Aeromonas salmonicida subsp. salmonicida (St30), виділені з видів прісноводних риб, таких як короп звичайний (Cyprinus carpio L.) та райдужная форель (Oncorhynchus mykiss Walbaum), відповідно, були отримані у Відділі захворювань риб Національного науково-дослідного ветеринарного інституту в Пулавах (Польща). Матеріал для бактеріологічних досліджень було виділено з риб із вираженими клінічними проявами захворювання. Намі результати свідчать про те, щзо три штамu Aeromonas (Aeromonas sobria, Aeromonas hydrophila, Aeromonas salmonicida subsp. salmonicida) виявили резистентність до етанольних екстрактів листків

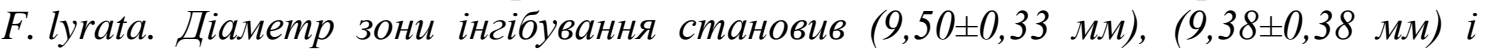
$(9,5 \pm 0,50$ мм) для Aeromonas sobria, Aeromonas hydrophila ma Aeromonas salmonicida subsp. salmonicida (St30), відповідно. Екстракт листків F. lyrata 'Bambino' виявив проміжну активність стосовно Aeromonas sobria (діаметр зони

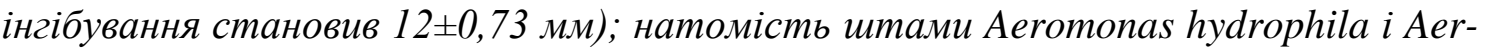
omonas salmonicida subsp. salmonicida (St30) виявили резистентність до дії екст-

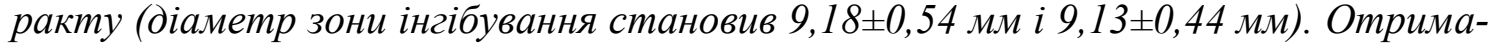
ні результати є передумовою для створення природних добавок, здатних замінити синтетичні. Відповідно, подільші дослідження, спрямовані на виділення активних сполук та їх фармакологічне дослідження як in vitro, так $i$ in vivo, $\epsilon$, на наш погляд, вкрай необхідними.

Ключові слова: Ficus lyrata, Ficus lyrata 'Bambino', Aeromonas sobria, Aeromonas hydrophila, Aeromonas salmonicida subsp. salmonicida, антимікробна активність, диско-дифузійний метод, етанольні екстракти.

DOI 10.32900/2312-8402-2019-122-30-42

УДК 639.3:615.32:615.38

\title{
EVALUATION OF OXIDATIVE STRESS BIOMARKERS LEVELS IN THE EQUINE BLOOD AFTER IN VITRO TREATMENT WITH SANSEVIERIA CAULESCENS N.E.BR. EXTRACT
}

Tkachenko H., Doctor of Biological Sciences

Osadowski Z., Doctor of Biological Sciences

Institute of Biology and Environmental Protection, Pomeranian University in Słupsk, Poland

Buyun L., Doctor of Biological Sciences

Maryniuk M., Post-graduatestudent

Kharchenko I., Ph.D.

M. M. Gryshko National Botanic Garden, National Academy of Science of Ukraine

The main goal of present study was to evaluate the level of the 2-thiobarbituric acid reactive substances (TBARS) as lipid peroxidation biomarker, aldehydic and ketonic derivatives of oxidatively modified proteins, and total antioxidant capacity in the equine erythrocytes' suspension induced by treatment of leaf extracts obtained from 
Sansevieriacaulescens N.E.Br. There were no significant changes for TBARS level between the value in the control group and in the equine erythrocytes' suspension after incubation with extracts derived from leaves of S.caulescens $(35.88 \pm 3.02 \mu \mathrm{mol} / \mathrm{L} v \mathrm{v}$. $35.04 \pm 2.31 \mu \mathrm{mol} / \mathrm{L})$. The level of aldehydic and ketonic derivatives of oxidatively modified proteins was non-significantly changed in the equine erythrocytes' suspension incubated with an extract obtained from the leaves of $S$. caulescens $(31.16 \pm 1.89 \mathrm{nmol} / \mathrm{mL}$ vs. $29.77 \pm 1.17 \mathrm{nmol} / \mathrm{mL}$ for aldehydic derivatives, $39.47 \pm 2.20 \mathrm{nmol} / \mathrm{mL}$ vs. $36.75 \pm 1.73 \mathrm{nmol} / \mathrm{mL}$ for ketonic derivatives of oxidatively modified proteins). The antioxidative and prooxidative mechanism of various Sansevieria species in equine erythrocyte suspension will be further studied in detail. Our study suggests that there were no significant changes for TBARS level as biomarker of lipid peroxidation, aldehydic and ketonic derivatives of oxidatively modified proteins, and total antioxidant capacity between values in control group and in the muscle tissue of rainbow trout after incubation with extracts from leaves of $S$. caulescens. Taking into account existing experimental evidence, it is reasonable to assume that secondary plant metabolites, i.e. polyphenolic compounds in the extract of S. caulescens may contribute to the antioxidant activity. In conclusion, the antioxidative and prooxidative mechanism of various Sansevieria species in equine erythrocyte suspension will be further studied in detail. The obtained information may be useful in the clinical usage of plants in medicine and veterinary. Finally, these findings justify the traditional uses of Sansevieriaplants for therapeutic purposes.

Keywords: Sansevieriacaulescens N.E.Br., horses, erythrocytes, 2thiobarbituric acid reactive substances (TBARS), aldehydic and ketonic derivatives of oxidatively modified proteins, total antioxidant capacity.

In recent years, the use of natural antioxidants present in various biological materials [i.e. phenolic compounds (flavonoids, phenolic acids, and alcohols, stilbenes, tocopherols, tocotrienols) ascorbic acid and carotenoids] has attracted considerable interest due to their presumed safety, nutritional and therapeutic value [1]. Antioxidants derived from plant materials, i.e. leaves, fruits, vegetables, spices, and cereals are very effective in the reduction of oxidative stress, increase the body's ability to use free radicals constructively to reduce the risks of chronic diseases and prevent disease progression $[12,31]$. Efforts to gain extensive knowledge regarding the power of antioxidants from plants and to tap their potential are therefore on the increase. Many medicinal plants have been investigated for their beneficial use as antioxidants or source of antioxidants using presently available experimental techniques [21].

In the current study, attention was focused onSansevieriaThunb., a genus with diverse ethnobotanical uses in its geographical distribution range, which occupies an important place among plant genera applied for treatment of a broad spectrum of diseases and disorders $[7,15,16,23,24,30]$. Our previous study [5, 6, 26-28] have highlighted the antibacterial capacity of ten species of Sansevieriagenus against Staphylococcus aureus. These plants have beenscreened in order to validate scientifically the inhibitory activity for microbial growth attributed to their popular use and to propose new sources of antimicrobial agents. TheleavesofSansevieriacanaliculataCarrière, $S$. trifasciataPrain, S. cylindricaBojer ex Hook., S. parva N.E.Br. (syn. S. dooneri N.E.Br.), S. fischeri (Baker) Marais, S. kirkii Baker, S. aethiopicaThunb., S. metallicaGérôme\&Labroy, S. caulescens N.E.Br., S. francisiiChahin were used. Our results proved that the zones of inhibition ranged from 16 to $34 \mathrm{~mm}$. Extracts from the leaves of $S$. fischeri and S. francisii were particularly active against tested organism (inhibition 
zones comprise up to $34 \mathrm{~mm}$ in diameter). This was followed by the activities of extracts from the S. parva, S. kirkii, S. aethiopica, S. caulescens, S. metallica leaves (diameters of inhibition zones ranged from 25 to $31 \mathrm{~mm}$ ). The ethanolic extracts of $S$. canaliculata and $S$. trifasciata showed less antimicrobial activities (diameters of inhibition zones ranged between 16 and $16.5 \mathrm{~mm}$ ). The results proved that the ethanolic extracts from S. fischeri, S. francisii, S. parva, S. kirkii, S. aethiopica, S. caulescens, S. metallica exhibit a favorable antibacterial activity against $S$. aureus $[5,6,26,27]$.

In our previous study, we also studied the antioxidant activity of extracts obtained from leaves of selected species from Sansevieria species against oxidative stress using equine erythrocyte suspension [28]. When erythrocytes were incubated with leaf extracts of various Sansevieria species, the aldehydic derivatives level was significantly reduced by $13.6 \%(\mathrm{p}<0.05)$ for $S$. forskaliana extract. Moreover, all extracts (except $S$. francisii extract) reduced the formation of intracellular aldehydic derivatives of oxidatively modified proteins (OMP) in the extracts-treated erythrocytes, but these results were non-significant. Treatment by extracts of various Sansevieria species reduced the concentration of ketonic derivatives of OMP when compared to untreated erythrocytes. The most potent effect was demonstrated by the $S$. canaliculata, S. forskaliana, $S$. aethiopica, S. cylindrica, S. metallica, S. hyacinthoides, and S. kirkii compared to control samples (phosphate buffer) $(16.1,14.7,13.4,12.9,12.9,12.7,12.1 \%$, respectively). However, there were no significant changes in other extracts. The experimental evidence obtained in our previous study indicated that various species of Sansevieria genus are a rich source of compounds that manifest antioxidant activity and can effectively protect erythrocytes against oxidative-induced damage. Thus, $S$. canaliculata, $S$. forskaliana, S. aethiopica, S. cylindrica, S. metallica, S. hyacinthoides, and S. kirkiimay be a valuable source of natural antioxidants that may potentially be recommended for applications in medicine and veterinary practice. According to the above-mentioned antioxidant mechanisms, extracts of various species from Sansevieria genus may inhibit the formation of protein carbonyl by scavenging free radicals formed in vitro. According to many supporting documents, it can be assumed that secondary plant metabolites, i.e. polyphenolic compounds in extracts of various species from Sansevieriagenus extract may contribute to the antioxidant activity [28].

The erythrocytes of mammals represent a good model to evaluate the cytotoxicity of molecules, organic and inorganic, natural or synthetic, by cellular damage measure [22]. The erythrocyte could be isolated and handled easily so that they could provide a good model for many assays $[2,9]$. Additionally, the high concentration of polyunsaturated fatty acids in RBCs membrane, the high oxygen tension, and redox active hemoglobin molecules [the source of reactive oxygen species in erythrocyte] make them a good biological lipid membrane model especially for screening the oxidative stress conditions induced by various substances [9].

Therefore, the main goal of present study was to evaluate the level of the 2thiobarbituric acid reactive substances (TBARS) as lipid peroxidation biomarker, aldehydic and ketonic derivatives of oxidatively modified proteins, and total antioxidant capacity in the equine erythrocytes' suspension induced by treatment of leaf extracts obtained from Sansevieriacaulescens N.E.Br.

Materials and methods. Collection of plant material. The leaves of Sansevieriacaulescens plants, cultivated under glasshouse conditions, were sampled at M. M. Gryshko National Botanic Garden (NBG), National Academy of Science of Ukraine (Fig. 1). 


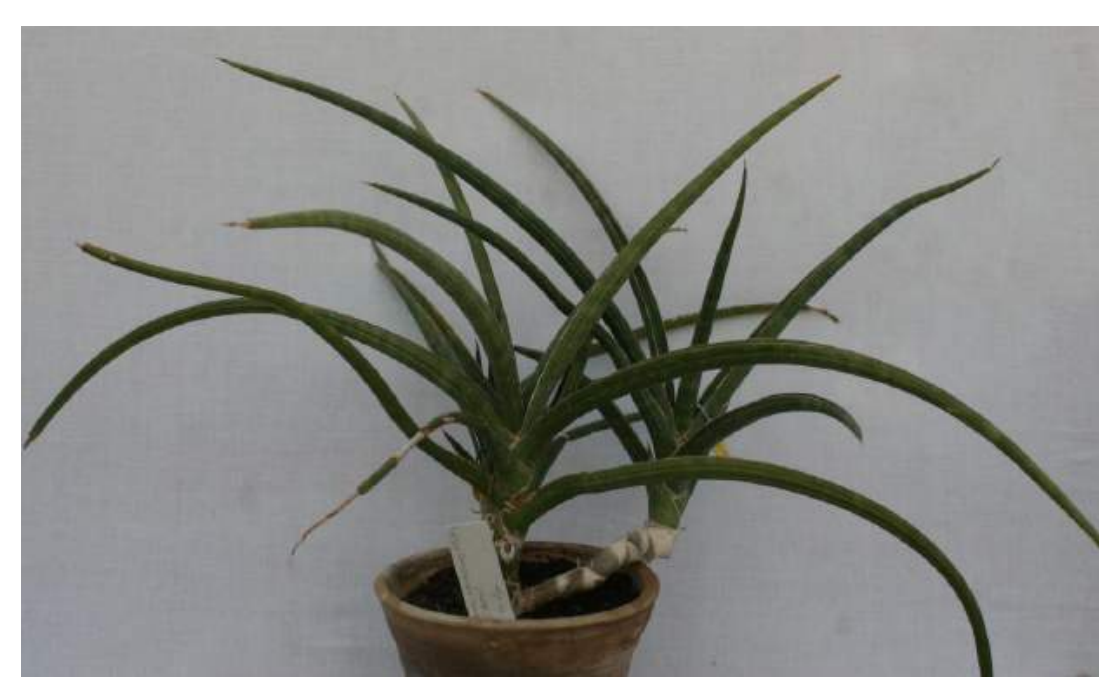

Fig. 1. General view of Sansevieriacaulescens N.E.Br. plant (Photo by Myroslava Maryniuk)
Preparation of plant extract. Freshly collected leaves were washed, weighted, crushed, and homogenized in $0.1 \mathrm{M}$ phosphate buffer $(\mathrm{pH}$ 7.4) (in proportion 1:19, $\mathrm{w} / \mathrm{w})$ at room temperature. The extract was then filtered and investigated for its antioxidant capacity. The extract was stored at $20^{\circ} \mathrm{C}$ until use.

Horses. Eighteen healthy adult horses from central Pomeranian region in Poland (village Strzelinko, N54 $30^{\prime} 48.0^{\prime}$ " E16 $\left.57^{\prime} 44.9^{\prime \prime}\right)$, aged $8.9 \pm 1.3$ years old, including 6 Hucul pony, 5 Thoroughbred horses, 2 Anglo-Arabian horses and 5 horses of unknown breed, were used in this study. All horses participated in recreational horseback riding. Horses were housed in individual boxes, with feeding (hay and oat) provided twice a day, at 08.00 and $18.00 \mathrm{~h}$, and water available ad libitum. All horses were thoroughly examined clinically and screened for hematological, biochemical and vital parameters, which were within reference ranges. The females were non-pregnant.

Collection of blood samples. Blood sampleswere taken simultaneously in all horses from the jugular vein in the morning, 90 minutes after feeding, while the horses were in the stables (between 8:30 and 10 AM). Whole blood was stored insterile tubes with sodium citrate as the anticoagulant and held on the ice until centrifugation at 3000 $\mathrm{rpm}$ for $5 \mathrm{~min}$ at $4^{\circ} \mathrm{C}$ using a refrigerated centrifuge to remove plasma. The separated erythrocytes were washed three times in $4 \mathrm{mM}$ phosphate buffer saline (PBS), $\mathrm{pH}=7.4$. After centrifugation, the supernatant and the buffy coat were carefully removed with each wash. Washed erythrocytes were finally re-suspended to the desired hematocrit level in $4 \mathrm{mM}$ PBS. The erythrocytes were stored at $4{ }^{\circ} \mathrm{C}$ and used within $2 \mathrm{~h}$ of sample preparation. A volume of $0.1 \mathrm{~mL}$ of the various extracts was added to $1.9 \mathrm{~mL}$ of clean equine erythrocyte suspension. For positive control, PBS was used. After incubation the mixture at $37^{\circ} \mathrm{C}$ for $60 \mathrm{~min}$ with continuous stirring, it was centrifuged at $3000 \mathrm{rpm}$ for $5 \mathrm{~min}$. Erythrocytes aliquots were used in the study.

Quantitative estimation of lipid peroxidation by determination of the 2thiobarbituric acid reactive substances (TBARS). The most important product of lipid peroxidation reacting with thiobarbituric acid (TBA) is malondialdehyde (MDA) [18]. Therefore, the lipid peroxidation was determined by quantifying the concentration of TBARS by Kamyshnikov (2004) for determining the malonic dialdehyde (MDA) concentration [13]. Briefly, $0.1 \mathrm{~mL}$ of erythrocyte suspension was added to $1 \mathrm{~mL}$ of $20 \%$ of trichloroacetic acid (TCA) and $1 \mathrm{~mL}$ of $0.8 \%$ of 2-thiobarbituric acid (TBA). The mixture was heated in a boiling water bath for $10 \mathrm{~min}$. After cooling, the mixture was centrifuged at 3,000 $\mathrm{g}$ for $10 \mathrm{~min}$. The absorbance of the supernatant was measured at $540 \mathrm{~nm}$. The concentration of MDA ( $\mu$ mol per L) was calculated using $1.5610^{5} \mathrm{mM}^{-1}$ $\mathrm{cm}^{-1}$ as the extinction coefficient.

The carbonyl derivatives content of protein oxidative modification $(\boldsymbol{O M P})$ as- 
say. To evaluate the protective effects of the extract against free radical-induced protein damage, a carbonyl derivatives content of protein oxidative modification (OMP) assay based on the spectrophotometric measurement of aldehydic and ketonic derivatives in the samples was performed. The rate of protein oxidative destruction was estimated from the reaction of the resultant carbonyl derivatives of amino acid reaction with 2,4dinitrophenylhydrazine (DNFH) as described by Levine and co-workers (1990) [17] and as modified by Dubinina and co-workers (1995) [8].DNFH was used for determining carbonyl content in soluble and insoluble proteins. Briefly, $1 \mathrm{~mL}$ of $0.1 \mathrm{M}$ DNPH (dissolved in $2 \mathrm{M} \mathrm{HCl}$ ) was added to $0.1 \mathrm{~mL}$ of the sample after denaturation of proteins by $20 \%$ trichloroacetic acid (TCA). After addition of the DNPH solution (or $2 \mathrm{M} \mathrm{HCl}$ to the blanks), the tubes were incubated for a period of $1 \mathrm{~h}$ at $37{ }^{\circ} \mathrm{C}$. The tubes were spun in a centrifuge for $20 \mathrm{~min}$ at $3000 \mathrm{~g}$. After centrifugation, the supernatant was decanted and $1 \mathrm{~mL}$ of ethanol-ethylacetate solution was added to each tube. Following the mechanical disruption of the pellet, the tubes were allowed to stand for $10 \mathrm{~min}$ and then spun again (20 min at 3,000 g). The supernatant was decanted and the pellet washed thrice with ethanol-ethylacetate. After the final wash, the protein was solubilized in $2.5 \mathrm{~mL}$ of $8 \mathrm{M}$ urea solution. To speed up the solubilization process, the samples were incubated in a $90^{\circ} \mathrm{C}$ water bath for $10-15 \mathrm{~min}$. The final solution was centrifuged to remove any insoluble material. The carbonyl content was calculated from the absorbance measurement at $370 \mathrm{~nm}$ and $430 \mathrm{~nm}$, and an absorption coefficient $22.000 \mathrm{M}^{-1} \cdot \mathrm{cm}^{-1}$. Carbonyl groups (nmol per mg of protein) were determined spectrophotometrically from the difference in absorbance at $370 \mathrm{~nm}$ (aldehydic derivatives, $\mathrm{OMP}_{370}$ ) and 430 $\mathrm{nm}$ (ketonic derivatives, $\mathrm{OMP}_{430}$ ).

Measurement of total antioxidant capacity $(\boldsymbol{T A C})$. The TAC level in the sample was estimated by measuring the 2-thiobarbituric acid reactive substances (TBARS) level after Tween 80 oxidation. This level was determined spectrophotometrically at 532 $\mathrm{nm}$ [10]. Sample inhibits the $\mathrm{Fe}^{2+} /$ ascorbate-induced oxidation of Tween 80, resulting in a decrease in the TBARS level. Briefly, $0.1 \mathrm{~mL}$ of sample was added to $2 \mathrm{~mL}$ of $1 \%$ Tween 80 reagent, $0.2 \mathrm{~mL}$ of $1 \mathrm{mM} \mathrm{FeSO}_{4}$, and $0.2 \mathrm{~mL}$ of $10 \mathrm{mM}$ ascorbic acid. In the blank assay, $0.1 \mathrm{~mL}$ of distilled water was used instead of the sample. The mixture was heated in a water bath for $48 \mathrm{hrs}$ at $37^{\circ} \mathrm{C}$. After cooling, $1 \mathrm{~mL}$ of $20 \%$ trichloroacetic acid was added. The mixture was centrifuged at $3000 \mathrm{~g}$ for $10 \mathrm{~min}$. After centrifugation, $2 \mathrm{~mL}$ of supernatant and $2 \mathrm{~mL}$ of $0.25 \% 2$-thiobarbituric acid were mixed. The mixture was heated in a water bath at $95^{\circ} \mathrm{C}$ for $15 \mathrm{~min}$. The absorbance of the obtained solution was measured at $532 \mathrm{~nm}$. The absorbance of the blank was defined as $100 \%$. The level of TAC in the sample (\%) was calculated with respect to the absorbance of the blank sample.

Statistical analysis. The mean \pm the standard error of the mean (S.E.M.) values were calculated for each group to determine the significance of the intergroup difference. All variables were tested for normal distribution using the Kolmogorov-Smirnov and Lilliefors test ( $\mathrm{p}>0.05$ ).In order to find significant differences (significance level, $\mathrm{p}<0.05)$ between groups, the the Mann-Whitney $U$ test by ranks was applied to the data [32]. All statistical analyses were performed using Statistica 8.0 software (StatSoft, Krakow, Poland).

Results and discussion. In a present study, we have studied the influence of extracts derived from leaves of S.caulescens on the TBARS level as biomarker of lipid peroxidation, aldehydic and ketonic derivatives of oxidatively modified proteins and the total antioxidant capacity in the equine erythrocytes' suspension after incubation with extract obtained from leaves of $S$. caulescensinin vitro culture. There were no significant changes for TBARS level between the value in the control group and in the equine 
erythrocytes' suspension after incubation with extracts derived from leaves of S. caulescens $(35.88 \pm 3.02 \mu \mathrm{mol} / \mathrm{L}$ vs. 35.04 $\pm 2.31 \mu \mathrm{mol} / \mathrm{L})$ (Fig. 2).

Similarly, the level of aldehydic and ketonic derivatives of oxidatively modified proteins was non-significantly changed in the equine erythrocytes' suspension incubated with an extract obtained from the leaves of $S$. caulescens $(31.16 \pm 1.89 \mathrm{nmol} / \mathrm{mL} v s$. $29.77 \pm 1.17 \mathrm{nmol} / \mathrm{mL}$ for aldehydic derivatives, $39.47 \pm 2.20 \mathrm{nmol} / \mathrm{mL} \quad v s$. $36.75 \pm 1.73 \mathrm{nmol} / \mathrm{mL}$ for ketonic derivatives of oxidatively modified proteins) (Fig. 2).

The total antioxidant capacity (TAC) determines the ability of a tested material to neutralize oxygen-free radical specific form, irrespectively to the specific antioxidant activity of present antioxidants [29]. Our results showed that extract of S. caulescens efficiently increased the TAC level by $1 \%(\mathrm{p}>0.05)$ due to inhibited the $\mathrm{Fe}^{2+} /$ ascorbateinduced oxidation of Tween 80, resulting in a decrease in the TBARS level (Fig. 2).
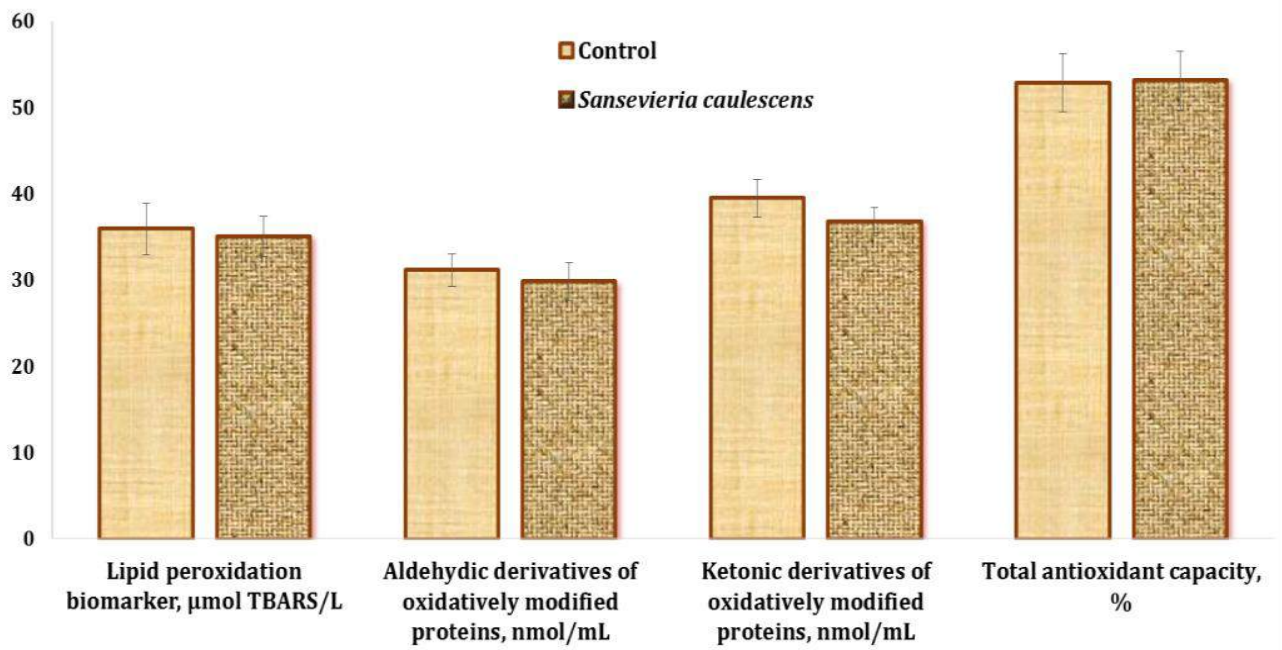

Fig. 2. The level of 2-thiobarbituric acid reactive substances (TBARS), aldehydic and ketonic derivatives of oxidatively modified proteins andtotal antioxidant capacity in the equine erythrocytes' suspension induced by treatment of leaf extracts obtained from Sansevieriacaulescens $(M \pm m, n=18)$.

Our similar study suggests that the S.caulescens leaf extract has shown good antioxidant potential invitro study after incubation with muscle tissue homogenate of rainbow trout [20]. There were no significant changes for TBARS level as biomarker of lipid peroxidation, aldehydic and ketonic derivatives of oxidatively modified proteins between values in control group and in the muscle tissue of rainbow trout after incubation with extracts from leaves of S.caulescens. Nevertheless, our results showed that extract of $S$. caulescens efficiently increased the total antioxidant capacity in muscle tissue by $46.6 \%(\mathrm{p}<0.05)$ due to inhibited the $\mathrm{Fe}^{2+} /$ ascorbate-induced oxidation of Tween 80 , resulting in a decrease in the TBARS level. Taking into account existingexperimentalevidence, it is reasonable to assume that secondary plant metabolites, i.e. polyphenolic compounds in the extract of S.caulescens may contribute to the antioxidant activity. In conclusion, the results of this study provide a new perspective on the use of various Sansevieriaspecies as a medicinal plant to improve the antioxidant response of rainbow trout. Further studies including the use of other medicinal plants as food additives in aquaculture, the assessment of its antioxidant effects on various tissues are in progress. Finally, research needs to be focused on subjecting fish to these compounds to determine their effectiveness, stability, and impact both on the host and on the environment [20]. 
In our previous study we have evaluated the lipid peroxidation biomarkers and total antioxidant capacity in the muscle tissue of rainbow trout (Oncorhynchus mykissWalbaum) under incubation with extracts derived from the leaves of various Sansevier$i a$ species, aimed at the further improving methods for preventing and treating fish diseases by increasing the natural resistance of fish organism using antibacterial and antioxidant agents in aquaculture [20]. The most potent antioxidant effect was demonstrated for the extracts of $S$. caulescens, S. suffruticosa, S. hyacinthoides, S. canaliculata, $S$. aethiopica, S. gracilis, and S. parva as compared to phosphate buffer control (46.6, $66.8,77.3,49.8,71.1,63.4,39.4 \%$, respectively). The results showed that extracts of $S$. hyacinthoides and $S$. aethiopica efficiently increased the total antioxidant capacity in rainbow trout muscle tissue (Maryniuk et al., 2017). Among plant extracts screened for in vitro antioxidant properties in rainbow trout muscle tissue, the strongest toxicity responses were exhibited by $S$. cylindrica, $S$. canaliculata, $S$. trifasciata, $S$. metallica extracts [20].

On the other hand, many studies clearly demonstrate that various plants of Sansevieria genus are effective agents in the treatment and prevention of many diseases and disorders. For instance, Maheshwari and co-workers (2017) have studied the antioxidant and antiproliferative activities of SansevieriaroxburghianaSchult. and Schult. f. methanol extract and its fractions [19]. Significant antioxidant and anti-proliferate activity were detected in the ethyl acetate fraction. Ethyl acetate fraction showed prominent scavenging activity in 1,1-diphenyl-2-picrylhydrazyl, 2,2'-azino-bis (3ethylbenzothiazoline-6-sulfonic acid) diammonium salt, and nitric oxide antioxidant assays with a concentration yielding $50 \%$ inhibition $\left(\mathrm{IC}_{50}\right) 15.33 \pm 1.45,45.3 \pm 1.93$ and $48.43 \pm 0.46 \mathrm{mg} / \mathrm{ml}$, respectively. Cytotoxicity of ethyl acetate fraction was the highest among other fractions against HCT-116, HeLa, and MCF-7cancer cell lines with IC50 values $16.55 \pm 1.28,12.38 \pm 1.36$, and $8.03 \pm 1.9 \mu \mathrm{g} / \mathrm{ml}$, respectively, by MTT assay and $15.57 \pm 0.70,13.19 \pm 0.49$, and $10.34 \pm 0.9 \mu \mathrm{g} / \mathrm{ml}$, respectively, by SRB assay. The presence of gallic acid in the ethyl acetate fraction of $S$. roxburghiana rhizomes was confirmed by HPLC and HPTLC analysis. Results of Maheshwari and coworkers (2017) suggested that the ethyl acetate fraction exhibited effective antioxidant and antiproliferative activities. The phenolic compounds identified in the ethyl acetate fraction could be responsible for the activities [19].

The antioxidative and antimutagenic capacities of the methanolic extracts derived from the leaves and rhizomes ofS. cylindricaandS. trifasciatahave been assessed by Karamovaand co-workers (2016). This study was focused of the following parameters: inhibitory activity onlipid peroxidation, suppressing ability on direct-acting mutagensodium azide-induced mutagenesis inSalmonella typhimuriumcells [14].The preliminary phytochemical screening of leaf extracts of $S$. cylindrica revealed the presence of various compounds such as phenols, alkaloids, saponins, flavonoids, fatty acids and coumarins [25].

Sansevieriaroxburghiana rhizome has been claimed to possess antidiabetic activity in the ethnomedicinal literature in India. Therefore, experiments of Bhattacharjee and co-workers (2016) were carried out to explore the protective role of an edible (aqueous) extract of $S$. roxburghiana rhizome (SR) against experimentally induced type 2 diabetes mellitus (T2DM) and its associated cardiomyopathy in Wistar rats [4]. SR was chemically characterized by GC-MS analysis. Antidiabetic activity of SR (50 and $100 \mathrm{mg} / \mathrm{kg}$, orally) was measured in high-fat diets (ad libitum) + low-single dose of streptozotocin $(35 \mathrm{mg} / \mathrm{kg}$, intraperitoneal) induced type 2 diabetic (T2D) rat. Phytochemical screening of the crude extract revealed the presence of phenolic compounds, sugar alcohols, sterols, amino acids, saturated fatty acids within SR. T2D rats exhibited 
significantly $(\mathrm{p}<0.01)$ higher fasting blood glucose level with respect to control. Alteration in serum lipid profile $(\mathrm{p}<0.01)$ and increased levels of lactate dehydrogenase $(p<0.01)$ and creatine kinase $(p<0.01)$ in the sera revealed the occurrence of hyperlipidemia and cell destruction in T2D rats. T2DM caused significant $(\mathrm{p}<0.05-0.01)$ alteration in the biochemical markers in the sera. T2DM altered the redox status $(p<0.05-$ $0.01)$, decreased $(\mathrm{p}<0.01)$ the intracellular NAD and ATP concentrations in the myocardial tissues of experimental rats. While investigating the molecular mechanism, activation PKC isoforms were observed in the selected tissues. T2D rats also exhibited an upregulation in nuclear NF- $\kappa \mathrm{B}$ (p65) in the cardiac tissues. So, oral administration of SR (50 and $500 \mathrm{mg} / \mathrm{kg}$ ) could reduce hyperglycemia, hyperlipidemia, membrane disintegration, oxidative stress, vascular inflammation and prevented the activation of oxidative stress-induced signaling cascades leading to cell death. Histological and ultrastructural studies of cardiac tissues supported the protective characteristics of SR. Therefore, findings of Bhattacharjee and co-workers (2016) suggest that SR could offer protection against T2DM and its associated cardiotoxicity via multiple mechanisms viz. hypoglycemic, antioxidant and anti-inflammatory actions [4].

Moreover, $S$. roxburghiana rhizome exhibited remarkable antitumor activity in Swiss mice that are plausibly attributable to its augmenting endogenous antioxidant mechanisms. Haldar and co-workers (2010) have evaluated the hydroalcoholic extract of $S$. roxburghiana rhizome (HASR) for antitumor activity against Ehrlich ascites carcinoma (EAC) in Swiss albino mice [11]. Twenty-Four hours after intraperitoneal inoculation of tumor (EAC) cells in mice, HASR was administered at 50 and $100 \mathrm{mg} / \mathrm{kg}$ body weight for nine consecutive days. On day 10 half of the mice were sacrificed and rest were kept alive for assessment of the increase in life-span. The antitumor effect of HASR was assessed by evaluating tumor volume, packed cell count, viable and nonviable tumor cell count, median survival time and increase in life-span of EAC bearing hosts. Hematological profiles and serum biochemical parameters were estimated. Further, antioxidant properties were assessed by estimating lipid peroxidation, reduced glutathione (GSH), superoxide dismutase (SOD) and catalase (CAT). HASR showed a significant $(\mathrm{p}<0.001)$ decrease in tumor volume, packed cell volume and viable cell count and increased the life span of EAC bearing mice. Hematological and serum biochemical profiles were restored to normal levels in HASR treated mice as compared to EAC control. HASR treatment significantly $(\mathrm{p}<0.001)$ decreased lipid peroxidation and recovered GSH, SOD, and CAT towards normal as compared to EAC control [11].

Andhare and co-workers (2012) have studied the antiallergic activity of ethanolic extract of Sansevieriatrifasciata (EEST), the plant eliciting analgesic, antiinflammatory, and antipyretic activity, on various animal models as well as in vitro conditions [3]. Ethanolic extract of $S$. trifasciata leaves (EEST) was prepared by cold maceration followed by concentration and evaporation under reduced pressure on a rotary evaporator to obtain semisolid mass. The various phytoconstituents were analyzed. The acute toxicity study of EEST was carried out in mice. The antiallergic and anaphylactic activities were evaluated using animal models viz. milk induced eosinophilia and leukocytosis, compound 48/80 induced mast cell degranulation, active and passive cutaneous anaphylaxis, and histamine-induced pedal edema. In addition, EEST effect on Shultz-Dale reaction in sensitized guinea pig ileum in ex vivo and antioxidant activity by free radical scavenging by DPPH method (in vitro) were also studied. EEST treatment at $100 \mathrm{mg} / \mathrm{kg}$ and $200 \mathrm{mg} / \mathrm{kg}$ p.o. inhibited (a) milk-induced increased eosinophilia, leukocytosis, monocytes, and neutrophils. (b) Prevented passive cutaneous and active anaphylactoid reactions. (c) Prevented compound 48/80 induced degranulation of sensitized mesenteric mast cells. (d) Inhibited histamine-induced pedal edema formation 
significantly. EEST pretreatment inhibited Shultz-Dale reaction in guinea pig ileum and also elicited potent antioxidant activity. Experimental findings of Andhare and coworkers (2012) have demonstrated promising antiallergic and anti-anaphylactic activity of EEST and also elicited potent antioxidant activity. The antiallergic and antianaphylactic activity might be due to inhibition of release of chemical mediators from mast cells largely by phytoconstituents like steroidal saponins, triterpenoids, and flavonoids present in EEST [3].

Conclusions. Our study suggests that there were no significant changes for TBARS level as biomarker of lipid peroxidation, aldehydic and ketonic derivatives of oxidatively modified proteins, and total antioxidant capacity between values in control group and in the muscle tissue of rainbow trout after incubation with extracts from leaves of $S$. caulescens. Taking into account existing experimental evidence, it is reasonable to assume that secondary plant metabolites, i.e. polyphenolic compounds in the extract of $S$. caulescens may contribute to the antioxidant activity. In conclusion, the antioxidative and prooxidative mechanism of various Sansevieria species in equine erythrocyte suspension will be further studied in detail. The obtained information may be useful in the clinical usage of plants in medicine and veterinary. Finally, these findings justify the traditional uses of Sansevieriaplants for therapeutic purposes.

\section{References}

1. Ahamad, T., Negi, D. S., Khan, M. F. (2017). Phytochemical analysis, total phenolic content, antioxidant and antidiabetic activity of Sansevieria cylindricaleaves extract. Journal of Natural Products and Resources, 3(2), 134-136. DOI: $10.21767 / 2472-0151.100026$.

2. Ajila, C. M., Naidu, K. A., Bhat, U. J. S., Rao, P. (2007). Bioactive compounds and antioxidant potential of mango peel extract. Food Chem., 105, 982-988. DOI: 10.1016/j.foodchem.2007.04.052.

3. Alagawany, M., Farag, M. R., El-Kholy, M. S., El-Sayed, S. A. A., Dhama, K. (2016). Effect of resveratrol, cinnamaldehyde and their combinations on the antioxidant defense system and ATP release of rabbit erythrocytes: in vitro study. Asian J. Anim. Sci. Vet. Adv., 12, 1-9. DOI: 10.3923/ajava.2017.1.9.

4. Andhare, R. N., Raut, M. K., Naik, S. R. (2012). Evaluation of antiallergic and anti-anaphylactic activity of ethanolic extract of Sanseveiriatrifasciata leaves (EEST) in rodents. J. Ethnopharmacol., 142(3), 627-633. DOI: 10.1016/ j.jep.2012.05.007.

5. Bhattacharjee, N., Khanra, R., Dua, T. K., Das, S., De, B., Zia-Ul-Haq, M., De Feo, V., Dewanjee, S. (2016). SansevieriaroxburghianaSchult. \& Schult. F. (Family: Asparagaceae) Attenuates Type 2 Diabetes and Its Associated Cardiomyopathy. PLoS One, 11(11), e0167131.DOI: 10.1371/journal.pone.0167131.

6. Buyun, L., Maryniuk, M., Tkachenko, H., Osadowski, Z. (2017). Antibacterial evaluation of an ethanolic extract from SansevieriatrifasciataPrain against Staphylococcus aureus. Proceedings of the International Scientific and Practical Internet Conference "Problems and perspectives of modern agricultural science". Mykolaiv : Mykolaiv SDDS IAZ, p. 88.

7. Buyun, L., Tkachenko, H., Osadowski, Z., Maryniuk, M. (2016). Antibacterial activity of certain Sansevieriaspecies against Staphylococcus aureus. Stupskie PraceBiologiczne, 13, 19-36.

8. Chhabra, S. C., Mahunnah, R. L. A., Mshiu, E. N. (1987). Plants used in traditional medicine in Eastern Tanzania. I. Pteridophytes and Angiosperms 
(Acanthaceae to Canellaceae). Journal of Ethnopharmacology, 21, 253-277. DOI: 10.1016/0378-8741(87)90103-6.

9. Dubinina, E. E., Burmistrov, S. O., Khodov, D. A., Porotov, I. G. (1995). Oxidative modification of human serum proteins. A method of determining it. Vopr. Med. Khim., 41, 24-26 [In Russian].

10. Farag, M. R., Alagawany, M. (2018). Erythrocytes as a biological model for screening of xenobiotics toxicity. Chem. Biol. Interact., 279, 73-83. DOI: 10.1016/ j.cbi.2017.11.007.

11. Galaktionova, L. P., Molchanov, A. V., Elchaninova, S. A., Varshavskiy, B. Y. (1998). The lipid peroxidation processes in patients with ulcerous illness of stomach and duodenum. Clin. Lab. Diagnostics, 6, 10-14 [In Russian].

12. Haldar, P. K., Kar, B., Bala, A., Bhattacharya, S., Mazumder, U. K. (2010). Antitumor activity of Sansevieriaroxburghiana rhizome against Ehrlich ascites carcinoma in mice. Pharm. Biol., 48(12), 1337-1343. DOI: 10.3109/ 13880201003792592.

13. Kahkonen, M. P., Hopia, A. I., Vuorela, H. J., Raucha, J. P., Pihlaja, K., Kujala, T. S. (1999). Antioxidant activity of plant extracts containing phenolic compounds. J. Agric. Food Chem., 47, 3954-3962. DOI: 10.1021/jf9901461.

14. Kamyshnikov, V. S. (2004). Reference book on clinic and biochemical researches and laboratory diagnostics,MEDpress-inform, Moscow [In Russian].

15. Karamova, N., Gumerova, S., Hassan, G. O., Abdul-Hafeez, E. Y., Ibrahim, O. H. M., Orabi, M. A. A., Ilinskaya, O. (2016). Antioxidant and antimutagenic potential of extracts of some Agavaceae family plants. BioNanoScience, 6(4), 591-593. DOI: 10.1007/s12668-016-0286-x.

16. Khalumba, M. L., Mbugua, P. K., Kung'u, J. B. (2005). Uses and conservation of some highland species of the genus Sansevieria Thunb. in Kenya. African Crop Science Conference Proceedings, 7, 527-532.

17. Kiringe, J. W. (2006). A survey of traditional health remedies used by the Maasai of Southern Kaijiado District, Kenya. Ethnobotany Research and Applications, 4, 61-73.

18. Levine, R. L., Garland, D., Oliver, C. N., Amici, A., Climent, I., Lenz, A.G., Ahn, B.-W., Shaltiel, S., Stadtman, E. R. (1990). Determination of carbonyl content in oxidatively modified proteins. Methods Enzymol., 186, 465-478. DOI: 10.1016/00766879(90)86141-h.

19. Lykkesfeldt, J. (2007). Malondialdehyde as biomarker of oxidative damage to lipids caused by smoking. Clin. Chim. Acta, 380,50-58. DOI: 10.1016/j.cca.2007.01.028.

20. Maheshwari, R., Shreedhara, C. S., Polu, P. R., Managuli, R. S., Xavier, S. K., Lobo, R., Setty, M., Mutalik, S. (2017). Characterization of the Phenolic Compound, Gallic Acid from SansevieriaroxburghianaSchult and Schult. f. Rhizomes and Antioxidant and Cytotoxic Activities Evaluation. Pharmacogn. Mag., 13 (Suppl 3), S693-S699. DOI: 10.4103/pm.pm_497_16.

21. Maryniuk, M., Tkachenko, H., Buyun, L., Kharchenko, I., Osadowski, Z. (2018). Oxidative stress biomarkers in the muscle tissue of the rainbow trout (Oncorhynchus mykissWalbaum) after in vitro treatment of Sansevieriacaulescens N.E.Br. extract. Agrobiodiversity for Improving Nutrition, Health and Life Quality, (2), 111-123. DOI: 10.15414/agrobiodiversity.2018.2585-8246.111-123.

22. PackiaLincy, M., Mohan, V. R., Jeeva, S. (2014). In vitro evaluation of antioxidant activity of aerial part of Maeruaapetala. Roth (Jacobs) (Capparaceae). Asian J. Pharm. Clin. Res., 7(2), 77-81. 
23. Pagano, M., Faggio, C. (2015). The use of erythrocyte fragility to assess xenobiotic cytotoxicity. Cell Biochem. Funct., 33(6), 351-355. DOI: 10.1002/cbf.3135.

24. Staples, G. W., Herbst, D. R. (2005). A Tropical Garden Flora: Plants cultivated in the Hawaiian Island and other tropical places. Bishop Museum Press, Honolulu, Hawaii.

25. Takawira-Nyenya, T., Newton, L.E., Wabuyele, E., Stedje, B. (2014). Ethnobotanical uses of SansevieriaThunb. (Asparagaceae) in Coast Province of Kenya. Ethnobotany Research and Application, 12(1), 51-69.

26. Tkachenko, H., Buyun, L., Osadowski, Z., Maryniuk, M. (2017). The antibacterial screening of certain Sansevieria species against Escherichia coli strain. Youth and Progress of Biology: Book of Abstracts of XIII International Scientific Conference for Students and Ph.D. Students (Lviv, 25-27 April 2017). Lviv, p. 220 221.

27. Tkachenko, H., Buyun, L., Osadowski, Z., Maryniuk, M. (2017). The antibacterial activity of certain SansevieriaThunb. species against Escherichia coli. Agrobiodiversity for improving nutrition, health, and life quality, 1, 446-453. DOI: 10.15414/agrobiodiversity.2017.2585-8246.446-453.

28. Tkachenko, H., Buyun, L., Pażontka-Lipiński, P., Witaszek, M., Osadowski, Z. (2017). In vitro protective effect of extracts obtained from various Sansevieria species against oxidative damage of proteins in equine erythrocytes. StupskiePraceBiologiczne, 14, 247-265.

29. Wang, H., Cao, G., Prior, R. L. (1997). Oxygen radical absorbing capacity of anthocyanins. J. Agric. Food Chem., 45(2), 304-309. DOI: 10.1021/jf960421t.

30. Watt, J. M., Breyer-Brandwijk, M. G. (1962). The Medicinal and Poisonous Plants of Southern and Eastern Africa. E \& S Livingstone Ltd., Edinburgh, Scotland.

31. Wolfe, K., Xianzhong, W. U., Liu, R. H. (2003). Antioxidant activity of apple peels. J. Agric. Food Chem., 51, 609-614. DOI: 10.1021/jf020782a.

32. Zar, J. H. (1999). Biostatistical Analysis. $4^{\text {th }}$ ed., Prentice-Hall Inc., Englewood Cliffs, New Jersey.

OПРЕДЕЛЕНИЕ IN VITRO УРОВНЯ БИОМАРКЕРОВ ОКИСЛИТЕЛЬНОГО СТРЕССА В СУСПЕНЗИИ КРОВИЛОШАДЕЙ ПОСЛЕ ВОЗДЕЙСТВИЯ ЭКСТРАКТА SANSEVIERIA CAULESCENSN. E.BR.

Ткаченко Г., Осадовский 3., Институт биологии и охраны окружающей среды Поморской Академии в Слупске

Буюн Л., Маринюк М., Харченко И., Национальный ботанический сад имени Н. Н. Гришко НАН Украины, Киев, Украина

Основная иеель данного исследования состояла в том, чтобы на экспериментальной модели окислительного стресса (суспензии эритроцитов лошадей) оченить уровень веществ, реагирующих с 2-тиобарбитуровой кислотой (TBARS), в качестве маркеров липидной пероксидации, альдегидных и кетоновых производных окислительно-модифицированных белков, общую антиоксидантную способность после воздействия in vitro экстракта листьев Sansevieria caulescens N.E.Br. Существенных отличий в значениях уровней TBARS в контроле и в суспензии эритроцитов лошадей после инкубации с экстрактами листьев S. caulescens

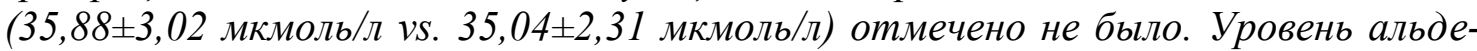
гидных и кетоновых производных окислительно-модифицированных белков в суспензии эритрочитов лошадей, инкубированной $c$ экстрактом листьев S. caulescens, также существенно не изменился $(31,16 \pm 1,89$ нмоль/мл vs.

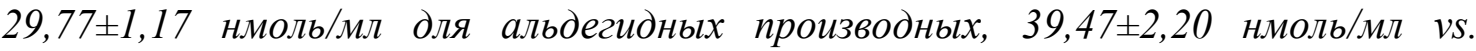


$36,75 \pm 1,73$ нмоль/мл для кетоновых производных окислительномодифицированных белков). Антиоксидантные и прооксидантные механизмы действия экстрактов листьев различных видов Sansevieria в суспензии эритроциитов лошадей требуют дальнейшего тщательного исследования. Проведенное исследование свидетельствует об отсутствии достоверных изменений уровня ТБАР как биомаркера перекисного окисления липидов, альдегидных и кетоновых производных окислительно модифицированных белков, а также общей антиоксидантной емкости между значениями в контрольной группе и в мышечной ткани радужной форели после инкубации с экстрактами из листьев S. caulescens. Принимая во внимание имеющиеся экспериментальные данные, можно предположить, что вторичные растительные метаболиты, т. е. полифенольные соединения в экстракте $S$. caulescens, могут вносить вклад в антиоксидантную активность. В заключение следует отметить, что антиоксидантный и прооксидантный механизм различных видов Sansevieria в суспензии эритроцитов лошадей будет подробно изучен в дальнейшем. Полученные сведения могут быть полезны при клиническом использовании растений в медицине и ветеринарии. Наконец, эти результать оправдывают традиционное использование Sansevieriaplants в терапевтических ичелях.

Ключевые слова: Sansevieria caulescens N.E.Br., лошади, эритрощуиты, веществва, реагирующие с 2-тиобарбитуровой кислотой (TBARS), альдегидные и кетоновые производные окислительно-модифицированных белков, общая антиоксидантная способность

\section{ВИЗНАЧЕННЯ IN VITRО РІВНІВ БІОМАРКЕРІВ ОКСИДАЦІЙНОГО СТРЕСУ В СУСПЕНЗІЇ КРОВІ КОНЕЙ ПІСЛЯ ОБРОБКИ ЕКСТРАКТОМ SANSEVIERIACAULESCENSN.E.BR.}

Ткаченко Г., Осадовський 3., Інститут біології та охорони навколишнього середовища Поморської Академії в Слупську

Буюн Л., Мирослава М., Харченко І., Начіональний ботанічний сад імені М. М. Гришка НАН України, Київ, Украӥна

Основна мета ицього дослідження полягала в тому, щуоб на експериментальній моделі окиснювального стресу (суспензії еритроцитів коней) визначити рівень речовин, щзо реагують з 2-тіобарбітуровою кислотою (TBARS), як маркерів ліпідної пероксидації, альдегідних та кетонових похідних окиснювальномодифікованих білків, загальну антиоксидантну здатність, індуковану обработкою екстрактом листків Sansevieriacaulescens N.E.Br. Iстотних відмінностей у значеннях рівнів TBARS у контролі та в суспензї еритроцитів коней після інкубування 3 екстрактами листків $S$. caulescens $(35,88 \pm 3,02$ мкмоль/л vs. 35,04 2,31 мкмоль/л) виявлено не було. Рівень альдегідних та кетонових похідних окиснювально-модифікованих білків в суспензії еритрочитів коней, інкубованій $з$ екстрактом листків S. caulescens, також істотно не змінився

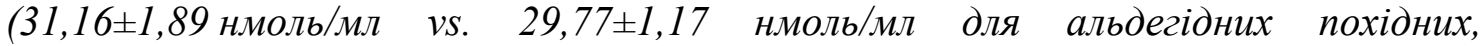

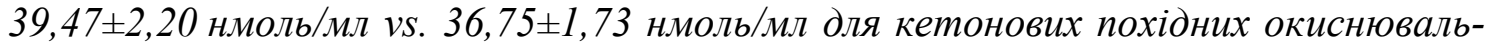
но-модифікованих білків). Антиоксидантні та прооксидантні механізми дії екстрактів листків різних видів Sansevieria в суспензї еритроцитів коней потребують подальшого ретельного дослідження. Проведене дослідження свідчить про відсутність достовірних змін рівня ТБАР як биомаркера перекисного окислення ліпідів, альдегідних і кетонових похідних окисно модифікованих білків, а також загальної антиоксидантної ємності між значеннями в контрольній групі і в м'язовій тканині райдужної форелі після інкубації з екстрактами з листків $S$. 
caulescens. Беручи до уваги наявні експериментальні дані, можна припустити, щуо вторинні рослинні метаболіти, тобто поліфенольні сполуки в екстракті $S$. caulescens, можуть вносити вклад в антиоксидантну активність. На закінчення слід зазначити, що антиоксидантний $і$ прооксидантний механізм різних видів Sansevieria в суспензії еритроцитів коней буде детально вивчений у подальшому. Отримані відомості можуть бути корисні при клінічному використанні рослин в медицині і ветеринарії. Нарешті, иүі результати виправдовують традиційне використання Сансевієріаплантатів в терапевтичних иілях.

Ключові слова: Sansevieria caulescens N.E.Br., коні, еритроцити, речовини, щзо реагують з 2-тіобарбітуровою кислотою (TBARS), альдегідні та кетонові похідні окиснювально-модифікованих білків, загальна антиоксидантна здатність.

DOI 10.32900/2312-8402-2019-122-42-50

УДК 636.2.034.083/084:591.3

\title{
ФОРМУВАННЯ ФУНКЦІОНАЛЬНИХ ОЗНАК МОЛОДНЯКУ УКРАЇНСЬКОЇ ЧОРНО-РЯБОЇ МОЛОЧНОЇ ПОРОДИ ЗА РІЗНИХ ТЕХНОЛОГІЙ УТРИМАННЯ ТА СЕЗОНУ НАРОДЖЕННЯ
}

\author{
Антоненко С. Ф. к. с.-г. наук, с. н. с. \\ Інститут тваринництва НААН
}

Технологія вирощування ремонтного молодняку великої рогатої худоби полягає у створенні таких умов утримання, які б сприяли розвитку бажаних якостей, кращому використанню тваринами поживних речовин корму більш інтенсивному росту і розвитку організму.

У статті наведено результати дослідження до удосконалення вирощування теличок української чорно-рябої молочної породи в ДП ДГ «Гонтарівка» Інституту тваринництва НААН Вовчанського району Харківської області. Було сформовано дві групи теличок зимового (по 12 голів) $i$ весняного сезону народження (по 14 голів) у кожній, вік тварин 4 місячі. Першу групу утримували безприв'язно (дослідна група), другу (контрольна) - прив'язно.

Встановлено, щчо фактичне споживання кормосуміші залежно від періоду досліджень $і$ групи теличок варіювало незначно. Телички дослідної групи, за їх утримання у групових секиіях безприв'язно мали більшу живу масу за перший мі-

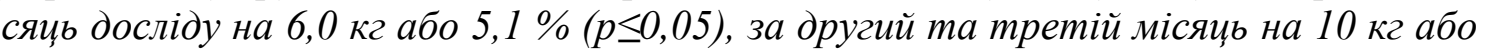

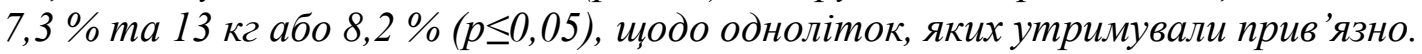

Подібна закономірність спостерігалась і в межах по другого періоду досліджень, за впливу весняного сезону народження теличок і системи утримання на живу масу.

Врахування фактичного споживання кормів та їх залишків дало змогу розрахувати витрати корму на 1 кг приросту живої маси, які в дослідній групі в периий період досліду варіювали від 4,14 до 4,17 кг корм. од. другий - від 3,32 до 3,74 кг корм. од., у контрольній групі відповідно - від 4,83 до 5,12 кг корм. од (перший період) та від 4,32 до 4,74 кг корм. од. (другий період). 